\title{
Procedure for Delisting a Site From the World Heritage List: Is Delisting With Consent or Against the Wish of a State Party Possible?
}

\author{
Eike Albrecht, Bénédicte Gaillard \\ Brandenburg University of Technology Cottbus-Senftenberg, Cottbus, Germany
}

\begin{abstract}
As of 2015 (UNESCO, 2015), the over-40-year-old Convention Concerning the Protection of the World Cultural and Natural Heritage (1972) has been ratified by 191 nations, making it a universal and internationally recognised instrument for the protection of cultural and natural heritage. In the meantime, 1007 World Heritage Sites have been inscribed on the World Heritage List (as of February 2015) and two sites have been delisted. This paper discusses the delisting procedure of a site from the World Heritage List based on the Operational Guidelines for the Implementation of the World Heritage Convention (henceforth OG). First of all, the question of the possibility to delist a site from the World Heritage List, in general, is addressed. And based on this discussion, the necessity of the consent of the State Party to the WHC on whose territory the site to be delisted is located is then examined.
\end{abstract}

Keywords: World Heritage Site, delisting, World Heritage in Danger, Dresden Elbe Valley, cultural landscape, World Heritage Convention (WHC), World Heritage Committee, Operational Guidelines for the Implementation of the WHC (OG)

\section{Introduction}

The first delisting ${ }^{1}$ of a World Heritage Site took place during the 31st session of the World Heritage Committee in 2007 (Christchurch, New Zealand). The Arabian Oryx Sanctuary (Oman) had been inscribed (UNESCO, 1994) as a natural site on the World Heritage List in 1994 and was delisted without a previous transfer to the List of World Heritage in Danger. The World Heritage Committee took this decision arguing that the reduction of the protected area under Omani Law of 90\% would damage the Outstanding Universal Value (henceforth OUV) and integrity of the site (UNESCO, 2007). The Dresden Elbe Valley (Federal Republic of Germany) constitutes the second World Heritage Site to be delisted. This cultural landscape had been inscribed ${ }^{2}$ on the World Heritage List in 2004 in Suzhou, China (UNESCO, 2004), but transferred ${ }^{3}$ to the List of World Heritage in Danger in 2006 in Vilnius, Lithuania (UNESCO, 2006) and delisted ${ }^{4}$ in 2009 in Seville, Spain (UNESCO, 2009). The World Heritage Committee took such a decision, arguing that the construction of a

\footnotetext{
Eike Albrecht, professor, head of the Department for Civil Law and Public Law, Brandenburg University of Technology Cottbus-Senftenberg. Email: albrecht@tu-cottbus.de.

Bénédicte Gaillard, Ph.D. of the International Graduate School (IGS), Brandenburg University of Technology Cottbus-Senftenberg.

${ }^{1}$ Decision 31 COM 7B.11 adopted at the 31st session of the World Heritage Committee, Christchurch, New Zealand.

2 Decision 28 COM 14B.40 adopted at the 28th session of the World Heritage Committee, Suzhou, China.

${ }^{3}$ Decision 30 COM 7B.77 adopted at the 30th session of the World Heritage Committee, Vilnius, Lithuania.

${ }^{4}$ Decision 33 COM 7A.26 adopted at the 33rd session of the World Heritage Committee, Seville, Spain.
} 
four-lane bridge, the Waldschlößchenbrücke, in the core of the protected area would destroy the OUV and integrity of the site.

While the delisting of a World Heritage Site is not regulated in the World Heritage Convention (WHC) (UNESCO, 1972), it is mentioned in the Operational Guidelines (OG) since their first version dating from $1977 .^{5}$

\section{Procedure of Delisting on the Basis of the OG}

While the mention of the delisting exists since the first version of the OG in 1977, the procedure for delisting is described in the OG since their revised version of 1980 (UNESCO, 1980, Paras. 24-32). But the procedure, as described in the latest version of the OG from 2013 (UNESCO, 2013, Paras. 192-198), is included since the revision of 2005. The World Heritage Committee, responsible of the OG, represents the main body in charge of the implementation of the WHC. The OG consist in (rather) precise criteria for the inscription of properties on the World Heritage List and for the provision of international assistance under the World Heritage Fund. The procedure of delisting is described in the fourth chapter of the OG dedicated to the "process for monitoring the state of conservation of world heritage properties". And the third part of this chapter is dedicated to the "procedure for the eventual deletion of properties from the World Heritage List". Para. 193 OG $^{6}$ states that States Parties to the WHC should "inform" the World Heritage Centre in the case of a serious deterioration of a World Heritage Site located on their territory. In the case that the World Heritage Centre would receive information on a World Heritage Site from another source rather than the State Party to the WHC, it would verify this information "in consultation" with the State Party and "request its comments", according to Para. 194 OG $^{7}$. Following Para. 196 OG $^{8}$, the World Heritage Committee shall take a decision based on WHC Art. 13, Para. $8^{9}$ and before taking the decision to delist a site, the State Party to the WHC should have been "consulted". In addition, according to Para. $197 \mathrm{OG}^{10}$, the State Party to the WHC should be "informed" of the decision of the World Heritage Committee.

To summarise, the delisting procedure is regulated in the OG, but only information and consultation between the State Party to the WHC and the World Heritage Committee are mentioned. However, the consent of the State Party to the WHC is not required. Furthermore, the reference to WHC Art. 13, Para. 8 indicates that the World Heritage Committee is required to take such a decision at the majority. Finally, the consequence of such a decision implies a modification of the World Heritage List and thus the delisting of a site. Nevertheless, since the OG are by legal nature considered as "soft law", they thus cannot change or amend binding provisions of the WHC.

\footnotetext{
5 "When a property included in the World Heritage List has deteriorated to such an extent that it has lost those characteristics for which it was inscribed thereon or when further research has shown that the property is not, in fact, of outstanding universal value, that property shall be deleted from the List” (UNESCO, 1977, Para. 5, iv).

6 "When a property inscribed on the World Heritage List has seriously deteriorated, or when the necessary corrective measures have not been taken within the time proposed, the State Party on whose territory the property is situated should so inform the Secretariat” (UNESCO, 2013, Para. 193).

7 "When the Secretariat receives such information from a source other than the State Party concerned, it will, as far as possible, verify the source and the contents of the information in consultation with the State Party concerned and request its comments" (UNESCO, 2013, Para. 194).

8 "The Committee will examine all the information available and will take a decision. Any such decision shall, in accordance with Article 13 (8) of the Convention, be taken by a majority of two-thirds of its members present and voting. The Committee shall not decide to delete any property unless the State Party has been consulted on the question” (UNESCO, 2013, Para. 196).

9 "Decisions of the Committee shall be taken by a majority of two-thirds of its members present and voting. A majority of the members of the Committee shall constitute a quorum" (WHC Art. 13, Para. 8).

10 “The State Party shall be informed of the Committee's decision and public notice of this decision shall be immediately given by the Committee” (UNESCO, 2013, Para. 197).
} 


\section{OG in Accordance With the WHC}

As of February 2015, there are 21 versions of the OG, the newest dating from July 2013 and the oldest from June 1977. They are drafted by the Secretariat of the World Heritage Committee and the advisory bodies as a "Main Working Paper". The OG are not mentioned in the WHC, but the World Heritage Committee revises them and they serve as an explanatory guide concerning the implementation of the WHC for the States Parties to the WHC. The OG might be considered as "flexible working documents", since they "are periodically revised to reflect the decisions of the World Heritage Committee". Thus, they seem to reflect "the interpretation of the WHC by the World Heritage Committee following the jurisprudence of its yearly sessions" (Gaillard, 2014, p. 155). However, since the States Parties to the WHC ratify only the WHC instead of the OG, the legal quality of the OG might be questioned. In this context, it can be argued, following Von Schorlemer (2008), that the OG consist in an internal document, that is, a secondary legislation, which is only binding for the institutions existing within the UNESCO, such as the World Heritage Committee. Furthermore, it can be added that the OG constitute an administrative act with external effects (Boisson de Chazournes, 2005). It can also be mentioned that the OG are compared, by Zacharias (2010), to external governance instruments or Verwaltungsvorschriften as defined in German law. Thus, even though the delisting procedure is described in the OG, since they do not have binding effects on the States Parties to the WHC and only the WHC does, the question of the delisting of a site from the World Heritage List has to be addressed with regard to the WHC. Nevertheless, the regulation concerning the delisting procedure does not exist in the WHC. Consequently, the following question might be raised: is delisting not possible because it is not explicitly mentioned in the WHC?

\section{Discussion}

In this context, it can be argued, while looking at WHC Art. $11^{11}$, that only the listing and the transfer to the List of World Heritage in Danger are regulated in the WHC, but the delisting not. First, the procedure of becoming a World Heritage Site takes place in three steps: (1) The individual State Party to the WHC

\footnotetext{
11 “1. Every State Party to this Convention shall, in so far as possible, submit to the World Heritage Committee an inventory of property forming part of the cultural and natural heritage, situated in its territory and suitable for inclusion in the list provided for in paragraph 2 of this Article. This inventory, which shall not be considered exhaustive, shall include documentation about the location of the property in question and its significance. 2. On the basis of the inventories submitted by States in accordance with paragraph 1, the Committee shall establish, keep up to date, and publish, under the title of "World Heritage List", a list of properties forming part of the cultural heritage and natural heritage, as defined in Articles 1 and 2 of this Convention, which it considers as having outstanding universal value in terms of such criteria as it shall have established. An updated list shall be distributed at least every two years. 3. The inclusion of a property in the World Heritage List requires the consent of the State concerned. The inclusion of a property situated in a territory, sovereignty, or jurisdiction over which is claimed by more than one State shall in no way prejudice the rights of the parties to the dispute. 4 . The Committee shall establish, keep up to date, and publish, whenever circumstances shall so require, under the title of "List of World Heritage in Danger", a list of the property appearing in the World Heritage List for the conservation of which major operations are necessary and for which assistance has been requested under this Convention. This list shall contain an estimate of the cost of such operations. The list may include only such property forming part of the cultural and natural heritage as is threatened by serious and specific dangers, such as the threat of disappearance caused by accelerated deterioration, large-scale public or private projects or rapid urban or tourist development projects; destruction caused by changes in the use or ownership of the land; major alterations due to unknown causes; abandonment for any reason whatsoever; the outbreak or the threat of an armed conflict; calamities and cataclysms; serious fires, earthquakes, landslides; volcanic eruptions; changes in water level, floods, and tidal waves. The Committee may at any time, in case of urgent need, make a new entry in the List of World Heritage in Danger and publicize such entry immediately. 5. The Committee shall define the criteria on the basis of which a property belonging to the cultural or natural heritage may be included in either of the lists mentioned in paragraphs 2 and 4 of this article. 6. Before refusing a request for inclusion in one of the two lists mentioned in paragraphs 2 and 4 of this article, the Committee shall consult the State Party in whose territory the cultural or natural property in question is situated. 7 . The Committee shall, with the agreement of the States concerned, co-ordinate and encourage the studies and research needed for the drawing up of the lists referred to in paragraphs 2 and 4 of this article" (WHC, Art. 11).
} 
nominates a domestic site for the World Heritage List following the requirements of "OUV", authenticity, and integrity; (2) The World Heritage Committee which consists in an elected group of 21 States Parties to the WHC decides the inscription, non-inscription, deferral, or referral of nominations for the World Heritage List with the assistance ${ }^{12}$ of the International Union for Conservation of Nature (henceforth IUCN) for natural heritage and the International Council on Monuments and Sites (henceforth ICOMOS) and the International Centre for the Study of the Preservation and Restoration of Cultural Property (henceforth ICCROM) for cultural heritage; and (3) The World Heritage Committee updates the World Heritage List, at least every two years. Second, the procedure of becoming a World Heritage Site in Danger is regulated in WHC Art. 11, Para. $4^{13}$. Consequently, the World Heritage Committee also administers a "List of World Heritage in Danger". The World Heritage Sites concerned are the sites threatened by serious and specific danger, such as the threat of disappearance caused by accelerated deterioration. In addition, the World Heritage Fund is created to help developing countries in the establishment and maintenance of sites of the two lists. Finally, there is no procedure mentioned on delisting sites.

Nevertheless, the delisting can be considered as indirectly maybe regulated while referring to the administration of the World Heritage List by the World Heritage Committee.

\section{Procedure of Delisting}

To argue that the delisting is possible, two questions need to be answered: (1) "Is delisting generally possible and who is competent?"; and (2) "Which procedure is required and is consent required for the delisting?”.

To answer the first question, it is necessary to take the existence of the List of World Heritage in Danger into account. The fact that the World Heritage Committee administers this list indicates that there might be consequences, if the threats for the site are not taken into consideration. Otherwise, the existence of such a list does not make sense. In addition, the World Heritage Committee is responsible for establishing, keeping up to date, and publishing the World Heritage List based on WHC Art. 11, Para. $2^{14}$. Furthermore, the competence of defining criteria for the inclusion of World Heritage Sites on either of the two lists is given to the World

\footnotetext{
12 "A representative of the International Centre for the Study of the Preservation and Restoration of Cultural Property (ICCROM), a representative of the International Council of Monuments and Sites (ICOMOS), and a representative of the International Union for Conservation of Nature and Natural Resources (IUCN), to whom may be added, at the request of States Parties to the Convention meeting in general assembly during the ordinary sessions of the General Conference of the United Nations Educational, Scientific, and Cultural Organization, representatives of other intergovernmental or non-governmental organizations, with similar objectives, may attend the meetings of the Committee in an advisory capacity” (WHC, Art. 8, Para. 3).

13 "The Committee shall establish, keep up to date, and publish, whenever circumstances shall so require, under the title of "List of World Heritage in Danger”, a list of the property appearing in the World Heritage List for the conservation of which major operations are necessary and for which assistance has been requested under this Convention. This list shall contain an estimate of the cost of such operations. The list may include only such property forming part of the cultural and natural heritage as is threatened by serious and specific dangers, such as the threat of disappearance caused by accelerated deterioration, large-scale public or private projects, or rapid urban or tourist development projects; destruction caused by changes in the use or ownership of the land; major alterations due to unknown causes; abandonment for any reason whatsoever; the outbreak or the threat of an armed conflict; calamities and cataclysms; serious fires, earthquakes, landslides; volcanic eruptions; changes in water level, floods, and tidal waves. The Committee may at any time, in case of urgent need, make a new entry in the List of World Heritage in Danger and publicize such entry immediately” (WHC, Art. 11, Para. 4).

14 "On the basis of the inventories submitted by States in accordance with paragraph 1, the Committee shall establish, keep up to date, and publish, under the title of "World Heritage List", a list of properties forming part of the cultural heritage and natural heritage, as defined in Articles 1 and 2 of this Convention, which it considers as having outstanding universal value in terms of such criteria as it shall have established. An updated list shall be distributed at least every two years” (WHC, Art. 11, Para. 2).
} 
Heritage Committee according to WHC Art. 11, Para. $5^{15}$. And the competence to decide in cases of request for international assistance is also given to the World Heritage Committee in accordance with WHC Art. 13, Para. $3^{16}$. Consequently, the answer to the first question is yes, because the World Heritage Committee is functioning as a master of the lists and decides which site is on the list and which is not, of course in accordance with the required procedures described in the OG. Furthermore, following the "Actus-contrarius theory", which means that an identical law by nature can amend another one (i.e., an administrative act can be amended, changed, or withdrawn by an administrative act), the decision of the World Heritage Committee to delist a site from the World Heritage List can thus amend the previous listing of this site.

To reply to the second question, the procedural provisions of the WHC in this context need to be elaborated upon. WHC Art. 11, Para. $1^{17}$ refers to the submission of an inventory by the States Parties to the WHC, which can be identified as the nomination. In WHC Art. 11, Para. 3, the inclusion of a World Heritage Site into the World Heritage List requires the consent of the State Party to the WHC concerned. Usually, this consent is given with the nomination. But the inclusion of a site to the World Heritage List against the will of a State Party to the WHC is not possible. In addition, according to WHC Art. 11, Para. $6^{18}$, consultation with the respective State Party to the WHC is required before refusing the inclusion of a site to the World Heritage List. In this context, while the consent is required for the listing, no consent is required for refusal of a nomination (only "consultation") and there is no provision for the inclusion of a site into the List of World Heritage in Danger.

While comparing with other international treaties, it can be demonstrated that consent is typically, in international law, required when a state should be burdened by a decision. This is the case with the Kyoto Protocol. ${ }^{19}$ In this context, it might be asked whether the inclusion to the list represents a burden to the States Parties to the WHC. Factually, it can be replied negatively because of the touristic potential and the marketing effect that the listing of a site represents and usually, the sites nominated are highly protected under the regulations of the States Parties to the WHC. But legally, it can be answered positively, because the inclusion of a site on the World Heritage List means extensive obligations for the States Parties to the WHC, in particular, the obligation to protect the site to the utmost of the state's resources.

Subsequently, the consent is not required, because the delisting is not burdening the State Party to the WHC, it is, from the perspective of international law, the opposite: it takes away a burden from the State Party to the WHC because with the delisting, the State Party to the WHC is not committed anymore to protect the site to the utmost of its own resources.

\footnotetext{
15 "The Committee shall define the criteria on the basis of which a property belonging to the cultural or natural heritage may be included in either of the lists mentioned in paragraphs 2 and 4 of this article” (WHC, Art. 11, Para. 5).

16 "The Committee shall decide on the action to be taken with regard to these requests, determine where appropriate, the nature and extent of its assistance, and authorize the conclusion, on its behalf, of the necessary arrangements with the government concerned" (WHC, Art. 13, Para. 3).

17 "Every State Party to this Convention shall, in so far as possible, submit to the World Heritage Committee an inventory of property forming part of the cultural and natural heritage, situated in its territory and suitable for inclusion in the list provided for in paragraph 2 of this Article. This inventory, which shall not be considered exhaustive, shall include documentation about the location of the property in question and its significance" (WHC, Art. 11, Para. 1).

18 "Before refusing a request for inclusion in one of the two lists mentioned in paragraphs 2 and 4 of this article, the Committee shall consult the State Party in whose territory the cultural or natural property in question is situated” (WHC, Art. 11, Para. 6).

19 "Amendments to Annexes A and B to this Protocol shall be adopted and enter into force in accordance with the procedure set out in Article 20, provided that any amendment to Annex B shall be adopted only with the written consent of the Party concerned" (United Nations Framework Convention on Climate Change, 1998, Art. 21, Para. 7).
} 


\section{Conclusion}

To summarise, even though the first delisting of a World Heritage Site took place only 35 years after the adoption of the WHC and 30 years after the first version of the OG was adopted, the delisting of a site from the World Heritage List is possible as shown in this paper. Although in the first case of delisting, the World Heritage Site was delisted at the request ${ }^{20}$, thus with the consent of the State Party to the WHC, and in the second case, the World Heritage Site was delisted without the consent ${ }^{21}$ of the State Party to the WHC, the consent is not required according to the provisions of the WHC.

Finally, the last question remains in view of WHC Art. $4^{22}$, which confers to the States Parties to the WHC the task to protect the cultural and natural heritage: although the delisting procedure is in accordance with the provisions of the WHC, is it also just?

\section{References}

Boisson de Chazournes, L. (2005). Treaty law-making and non-treaty law-making: The evolving structure of the international legal order. In R. Wolfrum, \& V. Röben (Eds.), Developments of international law in treaty making (pp. 463-480). Berlin, Heidelberg, New York: Springer.

Gaillard, B. (2014). Conflictive delisting process of a world heritage site in Germany: The case of the Dresden Elbe Valley (Ph.D. thesis, Brandenburgische Technische Universität, Cottbus, Germany).

UNESCO. (1972). Convention concerning the protection of the world cultural and natural heritage. Paris: UNESCO World Heritage Centre.

UNESCO. (1977). Operational guidelines for the World Heritage Committee. Retrieved from http://whc.unesco.org/archive/opguide77a.pdf

UNESCO. (1980). Operational guidelines for the implementation of the World Heritage Convention. Paris: UNESCO World Heritage Centre. Retrieved from http://whc.unesco.org/archive/opguide80.pdf

UNESCO. (1994). Convention concerning the protection of the world cultural and natural heritage. World Heritage Committee Eighteenth Session, Phuket, Thailand, WHC-94/CONF.003/16. Paris: UNESCO World Heritage Centre.

UNESCO. (2004). Convention concerning the protection of the world cultural and natural heritage. World Heritage Committee Twenty-eighth Session, Suzhou, China, WHC-04/28.COM/26. Paris: UNESCO World Heritage Centre.

UNESCO. (2006). Convention concerning the protection of the world cultural and natural heritage. World Heritage Committee Thirtieth Session, Vilnius, Lithuania, WHC-06/30.COM/19. Paris: UNESCO World Heritage Centre.

UNESCO. (2007). Convention concerning the protection of the world cultural and natural heritage. World Heritage Committee Thirty-first Session, Christchurch, New Zealand, WHC-07/31.COM/24. Paris: UNESCO World Heritage Centre.

UNESCO. (2009). Convention concerning the protection of the world cultural and natural heritage. World Heritage Committee Thirty-third Session, Seville, Spain, WHC-09/33.COM. Paris: UNESCO World Heritage Centre. Retrieved from http://whc.unesco.org/archive/2009/whc09-33com-summary.pdf

UNESCO. (2013). Operational guidelines for the implementation of the World Heritage Convention. Paris: UNESCO World Heritage Centre. Retrieved from http://whc.unesco.org/archive/opguide13-en.pdf

UNESCO. (2015). States parties: Ratification status. Retrieved from http://whc.unesco.org/en/statesparties/.

United Nations Framework Convention on Climate Change. (1998). Kyoto Protocol to the United Nations Framework Convention on Climate Change. Retrieved from http://unfccc.int/resource/docs/convkp/kpeng.pdf

\footnotetext{
20 “[The Observer Delegation of Oman] requested the Committee to respect the State Party's request to delete the property from the World Heritage List” (UNESCO, 2007, p. 82) and "The State Party appealed to the Committee to accept the State Party's request to delete the property from the List” (UNESCO, 2007, p. 85).

21 "View the World Heritage Site in Dresden in its entirety. Take the new legal situation into account in your decision. Give us time and please help us to achieve a consensus. Dresden is able and willing to contribute wherever it can” (UNESCO, 2009. p. 91).

22 "Each State Party to this Convention recognizes that the duty of ensuring the identification, protection, conservation, presentation, and transmission to future generations of the cultural and natural heritage referred to in Articles 1 and 2 and situated on its territory, belongs primarily to that State. It will do all it can to this end, to the utmost of its own resources and, where appropriate, with any international assistance and co-operation, in particular, financial, artistic, scientific, and technical, which it may be able to obtain” (WHC, Art. 4).
} 
Von Schorlemer, S. (2008). Compliance with the UNESCO World Heritage Convention: Reflections on the Elbe Valley and the Dresden Waldschlösschen Bridge. German Yearbook of International Law, 51, 321-390.

Zacharias, D. (2010). The UNESCO regime for the protection of world heritage as prototype of an autonomy-gaining international institution. In A. Bogdandy, R. Wolfrum, J. von Bernstorff, P. Dann, \& M. Goldmann (Eds.), The exercise of public authority by international institutions. Advancing international institutional law (pp. 301-336). Heidelberg: Springer. 